\title{
The effect of feeding magnesium-enriched diets on the quality of the albumen of stored eggs
}

\author{
By J. B. MONSEY AND D. S. ROBINSON* \\ $A R C$ Food Research Institute, Colney Lane, Norwich $N_{4}{ }_{7} U A$ \\ AND W. S. MILLER AND MARGARET ELLIS \\ Kennett Nutritional Centre, Spillers Ltd, Bury Road, \\ Kennett, Newmarket, Suffolk CB8 $8 Q U$
}

(Received 22 September 1975 - Accepted 3 November 1975)

\begin{abstract}
I. Pullets were given from I-d-old diets containing I.6, $4^{\cdot} \mathrm{I}, 8 \cdot \mathrm{I}$ and $\mathrm{I2} \cdot \circ \mathrm{g} \mathrm{Mg} / \mathrm{kg}$. Only small effects of these diets on live weight, food consumption, egg number, egg weights or egg-shell thickness were observed except at the highest level ( $12.0 \mathrm{~g} \mathrm{Mg} / \mathrm{kg}$ ) which caused diarrhoea and an appreciable lowering of the live weight of growing pullets. A further group was given from point-of-lay a diet containing $9.3 \mathrm{~g} \mathrm{Mg} / \mathrm{kg}$.

2. Eggs laid on 3 consecutive days from each of eighteen hens were collected at intervals of 3 weeks until the birds were 68.5 weeks old. Eggs laid on the 3 rd day were used to determine the initial proportion of thick egg-white present and also the concentration of $\mathrm{Mg}, \mathrm{Ca}, \mathrm{Na}$ and $\mathrm{K}$ in the thick egg-white. Eggs laid on the Ist and 2 nd days were stored at $20^{\circ}$ for $20 \mathrm{~d}$ to establish the proportion of thick egg-white remaining after storage.

3. With the unsupplemented diet the proportion of residual thick egg-white after storage of eggs for $20 \mathrm{~d}$ at $20^{\circ}$ was 306,161 and $305 \mathrm{mg} / \mathrm{g}$ total egg-white when the hens were $26 \cdot 5$, 53.5 and 68.5 weeks of age respectively. When the diet containing $9.3 \mathrm{~g} \mathrm{Mg} / \mathrm{kg}$ was given, the proportion of thick egg-white after storage remained approximately $400 \mathrm{mg} / \mathrm{g}$ throughout the period of the trial.

4. The mean $\mathrm{Mg}$ concentration in the thick egg-white of eggs laid by hens given unsupplemented diets was 5.77 mM. The addition of extra $\mathrm{Mg}$ to the diet increased the content of $\mathrm{Mg}$ in the thick egg-white, for example when the diet contained 9.3 $\mathrm{g} \mathrm{Mg} / \mathrm{kg}$ the mean concentration rose to $7.69 \mathrm{~mm}$.
\end{abstract}

The natural liquefaction of the thick egg-white fraction of the domestic hen's egg during the collection and marketing of eggs is one of the causes of poor internal egg quality (Monsey \& Robinson, I974), such eggs being down graded causing financial loss to the producer. Moreover, the use of eggs with low quality egg-white impairs the commercial baking properties of egg-white (Sills, 1974) and makes culinary operations, e.g. frying, physically difficult. We have shown, first, that $\mathrm{Mg}^{2+}$ can reduce ovomucin-lysozyme ( $E C$ 3.2.I.I7) interactions which may be responsible for the egg-white gel-to-sol transition (Robinson, 1972) and secondly that addition of $\mathrm{Mg}$ to isolated thick egg-white retards the natural thinning of the egg-white gel (Robinson \& Monsey, 1972). From these results and those of Sauveur (1971, 1973), it is apparent that $\mathrm{Mg}^{2+}$ has an important role in the stabilization of the thick egg-white gel, and hence the maintenance of a good internal quality in domestic eggs. This paper reports the results of experiments carried out to determine whether the feeding of Mg-enriched diets can enhance the stability of the egg-white gel. A preliminary communication describing some of the results has been published (Robinson, Monsey, Miller \& Clarke, r975.

Present address: Procter Department of Food and Leather Science, University of Leeds, Leeds LS2 9JT. 
Table I. Composition of basal diet $(\mathrm{g} / \mathrm{kg})$ given to laying hens

$\begin{array}{lc}\text { Maize } & 180 \\ \text { Wheat } & 190 \\ \text { Barley } & 370 \\ \text { White fish } & 40 \\ \text { Extracted soya-bean meal } & 70 \\ \text { Meat and bone meal } & 50 \\ \text { Grass meal } & 45 \\ \text { Vitamins } & \mathrm{r} \cdot 8 \\ \text { Methionine } & 0.66 \\ \text { Minerals } & 57 \cdot 8\end{array}$

MATERIALS AND METHODS

\section{Hens and diets}

A flock of $200 \mathrm{I}$-d-old pullets of a white egg strain, Babcock B 300 (supplied by Babcock Farms Ltd, Chelmsford), was divided into four groups of fifty chicks. One group was given a normal basal diet (Table $\mathrm{I}$ ) which contained $\mathrm{I} \cdot 5-\mathrm{I} \cdot 8 \mathrm{~g} \mathrm{Mg} / \mathrm{kg}$. The other groups were given the basal diet supplemented with $\mathrm{Mg}$ to give final concentrations of $4 . \mathrm{I}, 8 \cdot \mathrm{I}$ and $12.0 \mathrm{~g} \mathrm{Mg} / \mathrm{kg}$ respectively. The $\mathrm{Mg}$ was administered as an equimolar mixture of the chloride (hydrated) and the carbonate (hydrated, basic, light) salts (Fisons Ltd, Loughborough). At 2 I weeks of age, eighteen hens were randomly selected from each of the groups receiving diets containing $\mathrm{I} \cdot 6,4^{\cdot} \mathrm{I}$ and $8 \cdot \mathrm{Ig} \mathrm{Mg} / \mathrm{kg}$, put into wire-floored cages and each given a layer's diet with the same $\mathrm{Mg}$ content as they had received previously. A fourth group of eighteen birds which had received the unsupplemented diet up to $2 \mathrm{I}$ weeks of age was given a layer's diet containing 9.3 $\mathrm{g} \mathrm{Mg} / \mathrm{kg}$. The hens were fed $a d$ lib. and given tap water to drink.

Egg numbers, egg weight, food consumption and mortality rate were recorded throughout the laying period.

\section{Measurement of egg quality}

When the hens were 23.5 weeks old, all the eggs laid by each group on 3 consecutive days (days I, 2 and 3 ) were collected. Day I and 2 eggs were stored at $20^{\circ}$ for $20 \mathrm{~d}$. Day 3 eggs were broken within $5 \mathrm{~h}$ of collection and the proportion of thick egg-white of individual eggs measured by the method of Monsey \& Robinson (1974). The thick and total thin egg-white were separated by a standard mesh gauze and their weights recorded. This is a simplification of the method of Brooks \& Hale (1959), who determined the proportion of both the outer and the inner thin egg-white. The width of the square holes in the gauze and the diameter of the wire were $\mathrm{r} \cdot 36$ and $0.46 \mathrm{~mm}$ respectively. Day I and 2 eggs were broken after $20 \mathrm{~d}$ storage at $20^{\circ}$ and the proportion of residual thick egg-white in each egg measured. The above procedure was repeated at intervals of 3 weeks until the hens were 68.5 weeks old.

An experiment was carried out to compare two methods of egg-white quality assessment. When the hens were $72 \cdot 5$ weeks old, eggs were collected from each group on 4 consecutive days (days I, 2, 3 and 4 ) and stored for different periods of time (Table 5) at $20^{\circ}$. Within $5 \mathrm{~h}$ of collection from the laying cages day 4 eggs were broken and Haugh units (Haugh, 1937) were calculated from albumen height and egg weight 
Table 2. Effect of supplementation of diets with magnesium on daily live weight gain $(\mathrm{g})$ and daily food intake $(\mathrm{g})$ of pullets

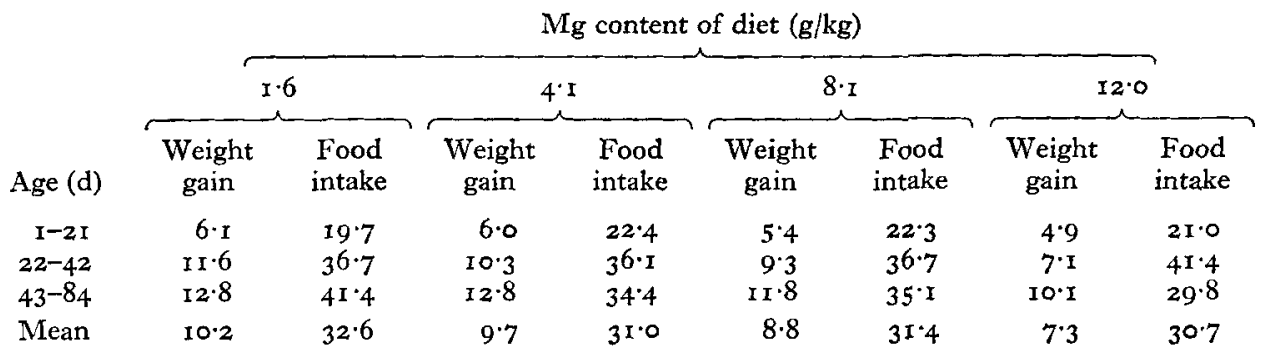

For significances see text.

Table 3. Effect of supplementation of diets with magnesium on egg production and food consumption of laying hens between 21 and 70 weeks

\begin{tabular}{|c|c|c|c|c|c|}
\hline & \multicolumn{4}{|c|}{$\mathrm{Mg}$ content of diet $(\mathrm{g} / \mathrm{kg})$} & \multirow[b]{2}{*}{ L.S.D.* } \\
\hline & $x \cdot 6$ & $4 \cdot 1$ & $8 \cdot 1$ & $9 \cdot 3$ & \\
\hline $\begin{array}{l}\text { Total no. of eggs laid by each } \\
\text { group of } 18 \text { hens }\end{array}$ & 4710 & 4905 & 3989 & $4 I I 7$ & \\
\hline Total no. of hen days & 6174 & 6174 & $555^{8}$ & 5999 & \\
\hline Total no. of eggs weighed & I 317 & 1371 & 962 & I 165 & \\
\hline Average weight of eggs $(\mathrm{g})$ & 59.0 & $58 \cdot 3$ & $58 \cdot 5$ & $57 \cdot 6$ & 0.5 \\
\hline Average egg mass/hen per $d(g)$ & $44 \cdot x$ & $45 \cdot 3$ & $4 I \cdot I$ & $40 \cdot 1$ & $2 \cdot 0$ \\
\hline No. of deaths & 0 & 0 & 5 & $\mathbf{I}$ & \\
\hline Average hen weight $(\mathrm{kg}) \dagger$ & $I \cdot 5 I$ & $\mathrm{I} \cdot 54$ & $\mathrm{I} \cdot 50$ & $1 \cdot 50$ & 0.03 \\
\hline Food consumption/hen per $d(g)$ & $108 \cdot 9$ & I I I 4 & $109 \cdot 8$ & 103.0 & $2 \cdot 0$ \\
\hline
\end{tabular}

measurements using an Egg-quality slide rule (distributed by the Kaw Co., $223 \mathrm{E}$ Hanover Street, Trenton, N.J., USA). The proportion of thick egg-white was also determined on the same eggs. Day I, 2 and 3 eggs stored at $20^{\circ}$ for 10,20 and $30 \mathrm{~d}$ respectively were similarly examined. These observations were also made after storage of eggs at $5^{\circ}$.

Measurements of shell thickness (membranes removed) were carried out on eggs laid by each group of hens on four different occasions. The mean value of three separate measurements made around the equator of the eggs was calculated.

\section{$\mathrm{Na}, \mathrm{K}, \mathrm{Ca}$ and $\mathrm{Mg}$ analysis}

Two duplicate $4 \mathrm{~g}$ samples of the isolated, combined and homogenized (MSE Ato-mix, slow speed) thick egg-white of the day 3 eggs from each group on ten occasions throughout the period of the trial were rapidly weighed, stored at $-20^{\circ}$ and analysed for $\mathrm{Na}, \mathrm{K}, \mathrm{Ca}$ and $\mathrm{Mg}$ by atomic adsorption spectrophotometry (Pye Unicam SP9o; Pye Unicam Ltd, Cambridge). 
Table 4. Effect of supplementation of diets with magnesium on quality of egg-white of fresh eggs

\begin{tabular}{|c|c|c|c|c|c|c|c|c|}
\hline \multirow{3}{*}{$\begin{array}{l}\text { Age of hen } \\
\text { (weeks) }\end{array}$} & \multicolumn{8}{|c|}{ Thick egg-white (mg/g total egg-white) } \\
\hline & \multicolumn{2}{|c|}{ A } & \multicolumn{2}{|c|}{ B } & \multicolumn{2}{|c|}{ C } & \multicolumn{2}{|c|}{$\mathrm{D}$} \\
\hline & Mean & SD & Mean & SD & Mean & SD & Mean & SD \\
\hline 23.5 & 656 & 80 & $64 r$ & 66 & 599 & 43 & 576 & 78 \\
\hline $26 \cdot 5$ & 571 & 85 & 590 & 57 & 556 & 69 & 574 & 76 \\
\hline $29 \cdot 5$ & 579 & 59 & 589 & 49 & $55^{8}$ & 55 & 582 & 65 \\
\hline 35.5 & 570 & 77 & 565 & 50 & 542 & 52 & 560 & $3^{8}$ \\
\hline $38 \cdot 5$ & 545 & 55 & $55 \mathrm{I}$ & 63 & 526 & 76 & $5^{81}$ & 43 \\
\hline $4 \pi \cdot 5$ & 510 & 71 & 530 & 54 & 519 & $6_{3}$ & 547 & 37 \\
\hline $44^{\cdot} 5$ & 527 & 52 & 523 & $6 \mathrm{I}$ & 508 & 45 & $55 \mathrm{I}$ & $5^{8}$ \\
\hline $47 \cdot 5$ & $5 \mp 5$ & 52 & 520 & 54 & $5 \times 3$ & 68 & 527 & 55 \\
\hline 50.5 & $50 \mathrm{I}$ & 69 & 511 & 67 & 471 & $5 \mathrm{I}$ & 509 & 29 \\
\hline 53.5 & 493 & 70 & $5 \mathrm{II}$ & 54 & 508 & 59 & 558 & 66 \\
\hline $56 \cdot 5$ & 483 & 59 & 499 & 68 & 422 & I74 & 519 & $4^{8}$ \\
\hline $59 \cdot 5$ & $5 \times 5$ & 59 & 517 & 62 & 539 & 64 & 524 & 45 \\
\hline $62 \cdot 5$ & 540 & 72 & 568 & 71 & $55^{\circ}$ & 43 & $5^{21}$ & 34 \\
\hline $65 \cdot 5$ & 584 & 73 & 584 & 72 & 582 & 91 & 595 & 37 \\
\hline $68 \cdot 5$ & 554 & 79 & 565 & 53 & 516 & 32 & 545 & 32 \\
\hline Mean & 543 & & $55^{\circ}$ & & 527 & & 552 & \\
\hline
\end{tabular}

A, diet containing $\mathrm{I} \cdot 6 \mathrm{~g} \mathrm{Mg} / \mathrm{kg}$ given from I d old; B, diet containing $4.1 \mathrm{~g} \mathrm{Mg} / \mathrm{kg}$ given from I d old; $\mathrm{C}$, diet containing $8 \cdot \mathrm{Ig} \mathrm{Mg} / \mathrm{kg}$ given from I d old; $\mathrm{D}$, diet containing $9.3 \mathrm{~g} \mathrm{Mg} / \mathrm{kg}$ given from $2 \mathrm{I}$ weeks of age.

\section{RESULTS}

\section{Statistical treatment}

Except where otherwise stated the data tabulated and analysed were the means of the measurements obtained on the eggs laid on a single day by the group of hens on each diet. Values were taken at various ages of hen. Analyses of variance were carried out with diet and age as factors using Duncan's multiple range test to investigate the differences between the diet means (taken over all ages) for significance at the $5 \%$ level.

\section{Effect of dietary $\mathrm{Mg}$ on live-weight gain, food consumption and egg production}

The pullets given a diet containing $12 \cdot 0 \mathrm{Mg} / \mathrm{kg}$ scoured noticeably, consequently it was decided to discontinue with this particular group. Analysis of variance on the data given in Table 2 showed that the effect of dietary $\mathrm{Mg}$ on average food intake of pullets was not significant. Average gain in live weight was, however, related to diet, the mean for the diet containing $12 \cdot 0 \mathrm{~g} \mathrm{Mg} / \mathrm{kg}$ being significantly lower than for the other diets but these were not significantly different from each other.

Over-all production figures for hens on the four diets is shown in Table 3. Chisquare analysis was used to investigate whether the proportion of total eggs laid to hen days was independent of diet. The proportion with the control diet was not significantly different from that with the $4^{\cdot} \mathrm{rg} \mathrm{Mg} / \mathrm{kg}$ diet but was significantly higher than those with the $8 . \mathrm{I}$ and $9.3 \mathrm{~g} \mathrm{Mg} / \mathrm{kg}$ diets. For the other data in Table 3 the means obtained 


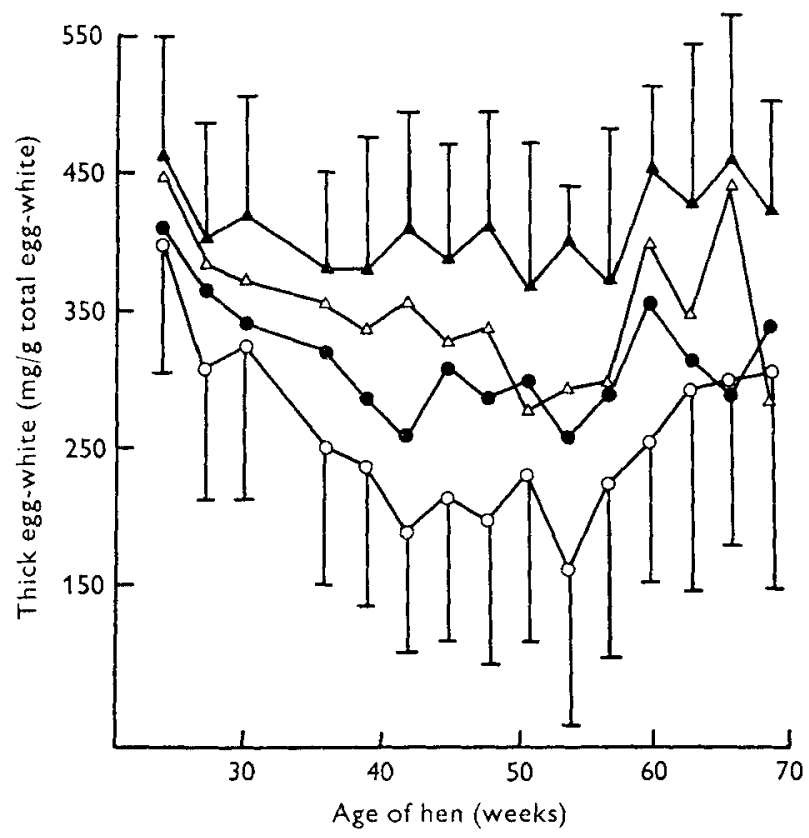

Fig. I. The effect of dietary magnesium and age of hen on the proportion of thick egg-white of eggs stored at $20^{\circ}$ for $20 \mathrm{~d}$. (O) diet containing $\mathrm{I} \cdot 6 \mathrm{~g} \mathrm{Mg} / \mathrm{kg}$ given from I d old; (O) diet containing $4^{\cdot 1} \mathrm{~g} \mathrm{Mg} / \mathrm{kg}$ given from I d old; $(\triangle)$ diet containing $8 \cdot \mathrm{I} \mathrm{g} \mathrm{Mg} / \mathrm{kg}$ given from I d old; (A) diet containing $9.3 \mathrm{~g} \mathrm{Mg} / \mathrm{kg}$ given from $2 \mathrm{I}$ weeks of age. Each point represents the mean thick egg-white content after storage of all eggs laid by eighteen hens from each group on two consecutive days. For the sake of clarity, standard deviations (as vertical bars) are shown for only two of the diets.

for each diet at different ages of hen were used to calculate least significant differences for the diet means. In all these analyses of variance age was a significant effect.

\section{Effect of dietary $M g$ on the proportion of thick egg-white before and after storage at $20^{\circ}$}

Analysis of variance of the data on average thick egg-white for unstored eggs (Table 4) and stored eggs (Fig. I) showed, in both cases, a significant dependence on diet and age of hen. For stored eggs, all diet means were significantly different; for unstored eggs, the mean for the $8 . \mathrm{I} \mathrm{g} \mathrm{Mg} / \mathrm{kg}$ diet was the only one which showed a significant difference from the means of the other three diets. (The reason for this last result is not understood.) For stored eggs, regression analysis was used to predict the proportion of thick egg-white, $\mathrm{TW}(\mathrm{mg} / \mathrm{g}$ ) from dietary $\mathrm{Mg}$ concentration $(\mathrm{g} \mathrm{Mg} / \mathrm{kg})$;

$$
\mathrm{TW}=17.8 \mathrm{Mg}+235(t=6.8, P<0.00 \mathrm{I}) .
$$

Age of hen was not a significant factor when included as a linear term in the regression equation but, when linear and quadratic components were included, both were highly significant $(P<0.001)$, and the regression coefficient with $\mathrm{Mg}$ was unchanged. Having corrected for the linear and quadratic effects of age, the partial correlation coefficient between TW and $\mathrm{Mg}$ was $0 \cdot 83$. 


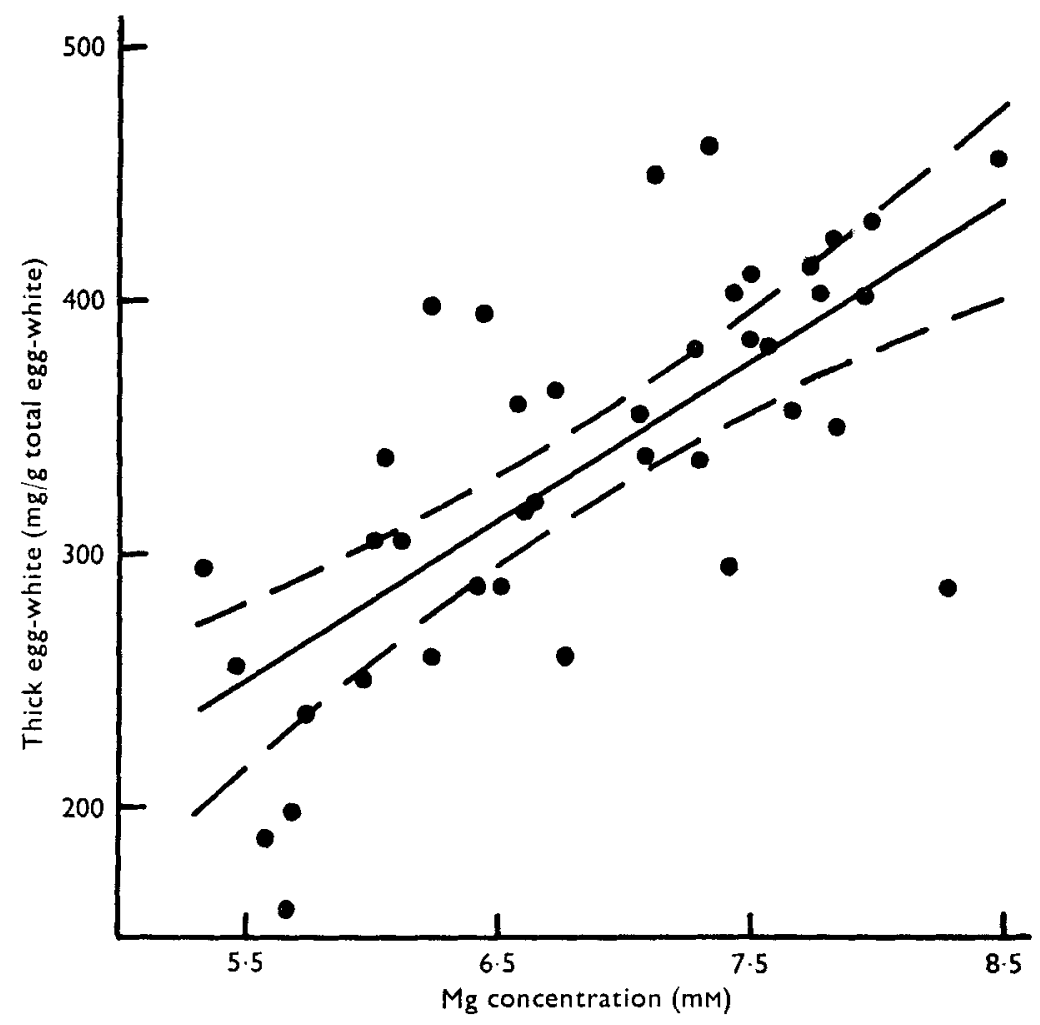

Fig. 2. Regression line for predicting the proportion of thick egg-white in hen's eggs after storage of eggs for $20 \mathrm{~d}$ at $20^{\circ}$ from the magnesium content of the thick egg-white. Each point represents the mean thick egg-white content after storage of all eggs laid by eighteen hens from each group on 2 consecutive days and also the mean $\mathrm{Mg}$ content of two duplicate samples of the pooled, unstored thick white from the same eighteen laid in I $d$. The samples were taken on ten occasions between 23.5 and 68.5 weeks of age. The broken lines show the $95 \%$ confidence limits of the regression equation (see below).

\section{Effect of dietary $\mathrm{Mg}$ on the $\mathrm{Mg}, \mathrm{Na}, \mathrm{K}$ and Ca contents of thick egg-white}

The $\mathrm{Mg}$ content of thick egg-white was not significantly affected by the age of the hen. The mean $\mathrm{Mg}$ contents for the $\mathrm{I} \cdot 6,4^{\cdot} \cdot \mathrm{I}, 8^{\circ} \mathrm{I}$ and $9 \cdot 3 \mathrm{~g} \mathrm{Mg} / \mathrm{kg}$ diets (Io estimations for each diet) were $5 \cdot 77,6 \cdot 50,7 \cdot 52$ and $7 \cdot 69 \mathrm{~mm}$ respectively. Except for the difference between the $8 \cdot 1$ and $9.3 \mathrm{~g} \mathrm{Mg} / \mathrm{kg}$ diets, all the means were significantly different.

The mean $\mathrm{Na}, \mathrm{K}$ and $\mathrm{Ca}$ contents of the same samples of thick egg-white were found to be $78^{\circ}, 40^{\circ} 4$ and $2 \cdot 2 \mathrm{mM}$ respectively. The concentrations of these metals were not related to the dietary $\mathrm{Mg}$ level.

Regression analysis was used to predict the proportion of thick egg-white, $\mathrm{TW}(\mathrm{mg} / \mathrm{g})$, from the $\mathrm{Mg}$ content, $\mathrm{C}(\mathrm{mM})$ of the thick egg-white. Fig. 2 shows the calculated relationship.

$$
\mathrm{TW}=63.5 \mathrm{C}-98.7(t=6.3, P<0.00 \mathrm{r}) .
$$

When included in the equation, age of hen was a significant factor (the correction to the predicted TW being a reduction of $5.0 \mathrm{mg} / \mathrm{g}$ between minimum and maximum age 
Vol. 37

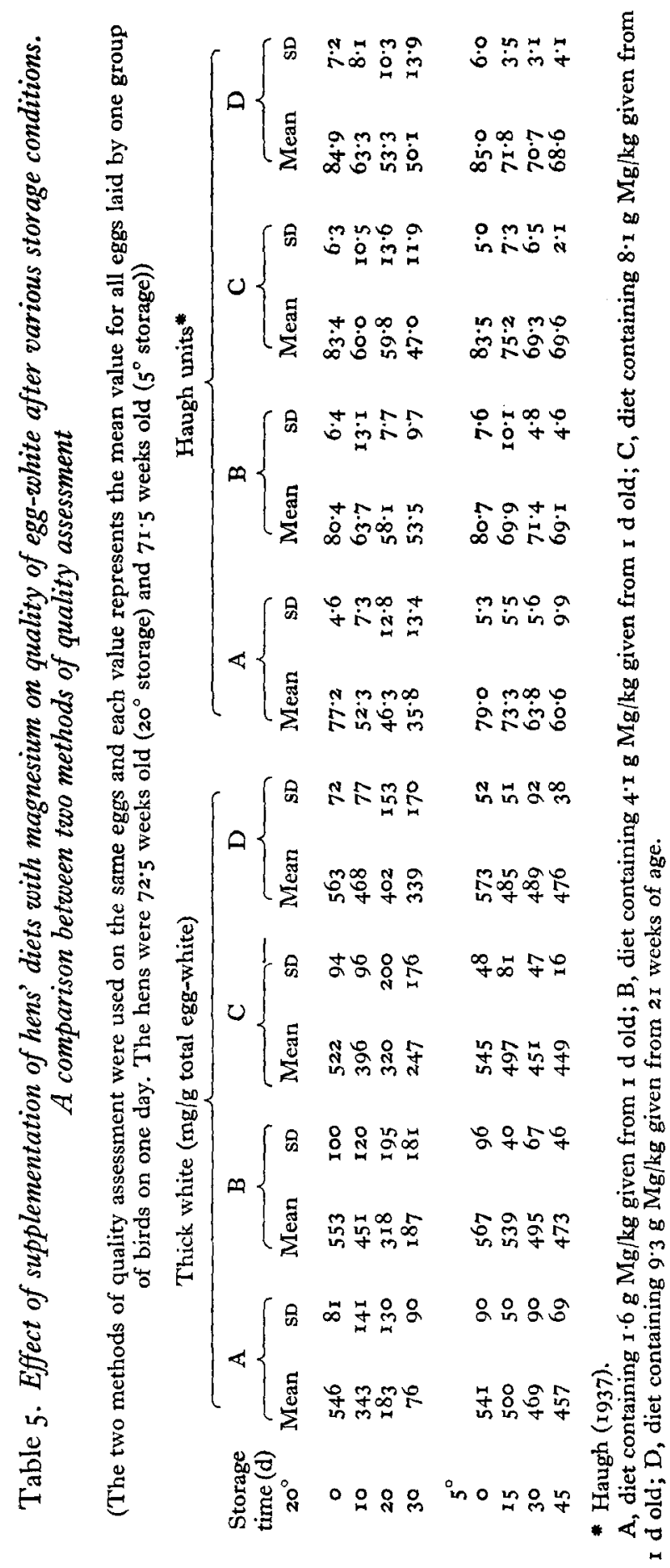


Table 6. Effect of supplementation of diets with magnesium on egg-shell thickness $(\mathrm{mm})$

(Values given are mean values for all eggs laid by one group of hens on I d (day 3))

\begin{tabular}{|c|c|c|c|c|c|c|c|c|c|}
\hline \multirow{4}{*}{$\begin{array}{c}\text { Age } \\
\text { of hen } \\
\text { (weeks) }\end{array}$} & \multicolumn{8}{|c|}{ Diet } & \multirow[b]{4}{*}{ Mean } \\
\hline & \multicolumn{2}{|c|}{ A } & \multicolumn{2}{|c|}{ B } & \multicolumn{2}{|c|}{ C } & \multicolumn{2}{|c|}{ D } & \\
\hline & 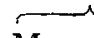 & $\rightarrow$ & 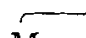 & 6 & & $\longrightarrow$ & $\rightarrow$ & {[} & \\
\hline & Mean & SD & Mean & SD & Mean & SD & Mean & $S D$ & \\
\hline $41 \cdot 5$ & 0.33 & 0.04 & 0.32 & 0.04 & 0.31 & 0.02 & 0.32 & 0.03 & 0.320 \\
\hline $50 \cdot 5$ & 0.32 & 0.03 & 0.32 & 0.03 & 0.32 & 0.04 & $0.3 I$ & 0.03 & 0.318 \\
\hline 59.5 & 0.31 & 0.05 & 0.30 & 0.04 & $0.3 I$ & 0.04 & 0.29 & 0.03 & 0.303 \\
\hline $72 \cdot 5$ & 0.30 & 0.05 & 0.29 & 0.05 & 0.28 & 0.03 & 0.27 & 0.02 & 0.285 \\
\hline Mean & $0.3 \times 5$ & & 0.308 & & 0.305 & & 0.298 & & \\
\hline
\end{tabular}

A, diet containing $\mathrm{r} \cdot 6 \mathrm{~g} \mathrm{Mg} / \mathrm{kg}$ given from I d old; B, diet containing $4.1 \mathrm{~g} \mathrm{Mg} / \mathrm{kg}$ given from I d old; $\mathrm{C}$, diet containing $8 . \mathrm{I} \mathrm{g} \mathrm{Mg} / \mathrm{kg}$ given from I d old; $D$ diet containing $9.3 \mathrm{~g} \mathrm{Mg} / \mathrm{kg}$ given from $2 \mathrm{I}$ weeks of age. For significances see text.

of hen) but the over-all significance of the multiple regression was less than that of the simple regression.

\section{Comparison of methods for assessing egg-white quality}

Eggs laid by the four groups of hens when they were 72.5 and 71.5 weeks of age were stored for varying times at $20^{\circ}$ and $5^{\circ}$ respectively. Results of the measurement of the proportion of thick egg-white are shown in Table 5. The corresponding values for Haugh units determined on the same eggs are also given. The effect of increased $\mathrm{Mg}$ levels in the diet could be detected in the thick egg-white after ro d storage at $20^{\circ}$ but became more evident after longer periods of storage. For example, after $30 \mathrm{~d}$ the mean proportion of thick egg-white was $76 \mathrm{mg} / \mathrm{g}$ using unsupplemented diets and $339 \mathrm{mg} / \mathrm{g}$ when the diet containing 9.3 $\mathrm{g} \mathrm{Mg} / \mathrm{kg}$ was given. The corresponding mean values for Haugh units were $35^{.8}$ and $5^{\circ} \cdot \mathrm{I}$ respectively. Smaller effects on the proportion of thick egg-white and on Haugh units were observed when eggs were stored at $5^{\circ}$. The relationship between thick egg-white and Haugh units was investigated for 246 eggs using individual results taken from various hens, diets and ages. The correlation coefficient was low $(r=0.6)$.

\section{Effect of dietary $\mathrm{Mg}$ on egg-shell thickness}

The mean egg-shell thicknesses in Table 6 were analysed and it was found that the only difference in diet means was between the 1.6 and $9 \cdot 3 \mathrm{~g} \mathrm{Mg} / \mathrm{kg}$ diets. Age of hen was also significant. The over-all mean egg-shell thickness was $0.306 \mathrm{~mm}$.

\section{$M g$ content of tap water}

The $\mathrm{Mg}$ concentration in the tap water was found to be $0.122 \pm 0.004 \mathrm{mmol} / \mathrm{l}$. It was calculated that the amount of $\mathrm{Mg}$ received by the laying hens from this source was negligible compared to the amount received from the diets. 


\section{DISCUSSION}

The results indicate that it is unnecessary to give supplementary $\mathrm{Mg}$, in order to achieve improved egg-white quality after storage, until the birds are near point-of-lay.

Egg production and egg weight were marginally lower when the supplemented diets were given although Staller \& Sunde (1964) reported that egg production and egg weight were not depressed over a period of 8 months as a result of giving diets containing up to $13 \mathrm{~g} \mathrm{Mg} / \mathrm{kg}$ given as dolomite (the double carbonate of $\mathrm{Mg}$ and $\mathrm{Ca}$ ).

Loose droppings were observed in pullets up to 12 weeks old when given the diet containing $12 \mathrm{~g} \mathrm{Mg} / \mathrm{kg}$. Other workers have reported higher water contents in the faeces of hens when the $\mathrm{Mg}$ concentration in the diet was higher than $9 \mathrm{~g} / \mathrm{kg}$ (Mehring $\&$ Johnson, 1965 ) or $13 \mathrm{~g} / \mathrm{kg}$ (Staller \& Sunde, 1964).

McWard (1967) states that hens receiving $12 \mathrm{~g} \mathrm{Mg} / \mathrm{kg}$ produced eggs with thinner shells than those receiving $4.8 \mathrm{~g} \mathrm{Mg} / \mathrm{kg}$. We also found egg-shells were thinner when the $\mathrm{Mg}$ level of the diet was raised.

The results show that feeding Mg-enriched diets to laying hens improved the quality of the albumen after storage. Roberson \& Francis (1966) claimed that Haugh units of newly laid eggs were unaffected by additional $\mathrm{Mg}$ (given as the sulphate). We found, however, that Haugh units of unstored eggs increase slightly with increasing $\mathrm{Mg}$ in the diet; this may be due to the different salts of $\mathrm{Mg}$ used.

The low correlation between Haugh unit and the proportion of thick egg-white values is probably because the two methods are monitoring different, although related physical changes during the thinning of thick egg-white. The Haugh unit is an observation essentially based on albumen height whilst the proportion of thick eggwhite is a measure of the volume of that part of egg-white which is more viscous than the thin egg-white. Brant, Otte \& Norris (195I) claimed that the determination of the amount of thick egg-white is more useful than using Haugh units for determination of egg-white quality in storage experiments and Brooks \& Hale (1959, 196r) have made extensive use of the method.

We have also shown that the $\mathrm{Mg}$ content of the thick egg-white fraction can be increased by feeding $\mathrm{Mg}$. In absolute terms the effect on concentration is small and may be within the natural variation between individual eggs. A substantial increase in the $\mathrm{Mg}$ content of the diet is required to improve egg-white quality although the total $\mathrm{Mg}$ content of the diets is still less than $10 \mathrm{~g} / \mathrm{kg}$.

The mechanism by which $\mathrm{Mg}$ improves the storage quality of egg-white is unknown. Previous work (Robinson, I 972 ) has shown that $\mathrm{Mg}$ depresses the interaction between reduced ovomucin and lysozyme in vitro. Hawthorne (1950) postulated that ovomucin complexes with lysozyme in such a way as to change the physical state of the ovomucin molecules and destroy the gel structure, and it can be argued that $\mathrm{Mg}$ is acting in this way. Alternatively, $\mathrm{Mg}^{2+}$ could be an inhibitor of enzymes responsible for the degradation of ovomucin (Robinson, 1972).

We thank Mrs V. Newby for her valuable assistance and R. Stansfield for computer statistical analysis. 


\section{REFERENCES}

Brant, A. W., Otte, A. W. \& Norris, K. H. (195I). Fd Technol., Champaign 5, 356.

Brooks, J. \& Hale, H. P. (1959). Biochim. Biophys. Acta 32, 237.

Brooks, J. \& Hale, H. P. (1961). Biochim. Biophys. Acta 46, 289.

Haugh, R. R. (1937). U.S. Egg Poultry Mag. 38 (2), 7o.

Hawthorne, J. R. (1950). Biochim. Biophys. Acta 6, 28.

McWard, G. W. (1967). Br. Poult. Sci. 8, 91.

Mehring, A. L. \& Johnson, D. Jr. (1965). Poult. Sci. 44, 853.

Monsey, J. B. \& Robinson, D. S. (1974). Br. Poult. Sci. 15, 369.

Roberson, R. H. \& Francis, D. W. (1966). Poult. Sci. 45, i i 19.

Robinson, D.S. (1972). In Egg Formation and Production, p. 65 [B. M. Freeman and P. E. Lake, editors]. Edinburgh: British Poultry Science Ltd.

Robinson, D. S. \& Monsey, J. B. (1972). F. Sci. Fd Agric. 23, 893.

Robinson, D. S., Monsey, J. B., Miller, W. S. \& Clarke, M. (1975). Proc. Nutr. Soc. 34, 45A.

Sauveur, B. (197I). Annls. Biol. anim. Biochim. Biophys. I1, 625.

Sauveur, B. (1973). Proc. 4th Eur. Poult. Conf., London, p. 477.

Sills, V. E. (1974). F. Sci. Fd Agric. 25, 989.

Staller, B. L. \& Sunde, M. L. (r964). Poult. Sci. 43, 1365. 